\title{
DISTRIBUTION OF SEAGRASS IN THE COAST OF BAHOI, MANEMBO-NEMBO AND TANDURUSA, NORTH SULAWESI, INDONESIA
}

\author{
Menajang Febry Susane Ivonne* \\ Postgraduate Program, Faculty of Fisheries and Marine Science, University of Brawijaya, \\ Malang, East Java \& Faculty of Fisheries and Marine Science, Sam Ratulangi University, \\ Manado, North Sulawesi, Indonesia
}

\author{
Herawati Endang Yuli, Mahmudi Mohammad, Yanuhar Uun \\ Faculty of Fisheries and Marine Science, University of Brawijaya, Malang, East Java, \\ Indonesia \\ Tanod Wendy Alexander \\ Institute of Fisheries and Marine (Sekolah Tinggi Perikanan dan Kelautan), Palu, \\ Central Sulawesi, Indonesia \\ *E-mail: febrymenajang@gmail.com
}

\begin{abstract}
Seagrass has important ecological functions, namely as a nursery-grown, spawning and protection areas for marine biota. In the world, there are 60 species of seagrasses, and in Indonesia, there are 14 species from 7 genera. The waters of North Sulawesi store a high potential of seagrass ecosystems. This study aimed to observe the distribution of seagrass from the Bahoi, Manembo-Nembo, and Tandurusa coast, North Sulawesi, Indonesia. Sampling carried out at the lowest ebb at the lunar or full moon phase. The method used for sampling is random, both for transect and squared lines. The results showed that from the Bahoi, Menembo-Nembo and Tandurusa coast, ten seagrass species from 7 genera and two families were found, namely Enhallus acoroides, Cymodocea rotundata, Cymodocea serrulata, Halodule uninervis, Halodule pinifolia, Halophila minor, Halophla ovalis, Syringodium isoetifolium, Thalassia hemprichii, dan Thalassodendron ciliatum. Information on seagrass distribution in an area can be taken into consideration for the government and related agencies in drafting a regulation in the management of seagrass ecosystem resources.
\end{abstract}

\section{KEY WORDS}

Cymodocea, Enhalus, Halodule, Halophila, Thalassia.

Seagrass is one of the plants in the shallow sea that is very productive. Seagrass plays an important role in supporting the life and development of biota in shallow seas, namely as a primary producer, habitat for biota, sediment, and nutrient trapping (Romimohtarto \& Juwana, 2005 and Hogarth, 2007). Seagrass is one of the coastal ecosystems formed by a single seagrass species or with a mixture of 2 to 12 seagrass species on the substrate (Kiswara \& Winardi, 1999). Phillips \& Menez (1988) reported that seagrasses have important ecological functions, namely as nursery-grown, spawning, and protected areas for marine biota such as fishes, shrimps, mollusks, starfish, and sea urchins. In addition Patty \& Rifai (2014) also reported marine biotas such as fish, crustaceans, mollusks (Pinna sp., Lambis sp., and Strombus sp.), Echinodermata (Holothuria sp., Synapta sp., Diadema sp., Arcbaster sp., Linckia sp.) and worms (Polychaeta) also live in seagrass ecosystems. Seagrass is a food for dugong (Dugong dugong) and green turtle (Chelonia mydas) (Lanyon, Limpus, \& Marsh, 1989).

In Indonesia, seagrasses grow in shallow coastal areas from the intertidal zone to the sub-coastal zone and around the waters of rocky islands (Pharmawati, Putra, Syamsuni, \& Mahardika, 2015). There are reportedly 60 species of seagrass in the world, and in 
Indonesia, there are 14 species from 7 genera (Supriyadi, 2012). Kiswara (2004) reported species of seagrass found in Indonesia, namely Thalassia hemprichii, Enhalus acoroides, Halodule uninervis, Halophila ovalis, Halodule pinifolia, Halophila decipien, Halophila spinulosa, Halophila sulawesii, Syringodium isoetifolium, Cymodocea rotundata, Thalassodendron ciliatum, Cymodocea serrulata, Halophila minor dan Ruppia maritim.

Indonesia is a tropical country in the Indo-Pacific region and is one of the seagrass distribution habitats. Seagrass function depends on the length and width of the leaf, the number of leaf strands, and total biomass. These factors determined by local conditions (Wangkanusa, Kondoy, \& Rondonuwu, 2017). (Supriyadi, 2012) reported that the middle part of Indonesia has a high level of diversity of seagrass species, compared to the western and eastern parts of Indonesia. The high diversity possible because the middle part of Indonesia included in the transition zone in the grouping of Wallace. The transition zone reported having high potential biota biodiversity (Tanod, Dewanto, Ndobe, Riyadi, \& Putra, 2019).

The waters of North Sulawesi stored a high potential of seagrass ecosystems. Preliminary studies on the distribution of seagrass species in the waters of North Sulawesi have been carried out. The study of literature known seagrass species found in North Sulawesi, which is a kind of Enhalus acoroides, Halophila ovalis, Thalassia hemprichii, Thalassodendron ciliatum, Cymodocea rotundata, Cymodocea serrulata, Halodule uninervis, Halodule pinifolia dan Syringodium isoetifolium. The dominant species, namely Enhalus acoroides (Irawan \& Matuankotta, 2015).

The study evaluated seagrass in North Sulawesi from waters of Mantehage (Patty \& Rifai, 2014); Bunaken (Wagey, 2017); Lembeh (Rustam et al., 2016); Tongkeina (Wagey \& Sake, 2013 and Wangkanusa et al., 2017); Mokupa (Amale, Kondoy, \& Rondonuwu, 2016); Bahoi (Yunitha, Wardiatno, \& Yulianda, 2014; Tolule, Kambey, \& Rondonuwu, 2015; and Fahruddin, Yulianda, \& Setyobudiandi, 2017); and Molas (Maabuat, 2012).

The literature study showed that research on the distribution of seagrass from the waters of Bahoi, Manembo-nembo, and Tandurusa, North Sulawesi, has not been done much. Based on the benefits and potential of seagrass for supporting marine life, research to see the distribution of seagrass in North Sulawesi needs to be done. This study aimed to observe the distribution of seagrass from the coast of Bahoi Likupang Barat, Manembonembo, and Tandurusa Bitung, North Sulawesi. This research adds information on the mapping of seagrass ecosystems in Indonesia, especially North Sulawesi.

\section{MATERIALS AND METHODS OF RESEARCH}

This research was conducted in the waters of the Bahoi, West Likupang District, North Minahasa Regency, Manembo-nembo and Tandurusa, Bitung City (Figure 1). The research location is in North Sulawesi, Indonesia. The study was conducted in July - August 2018. Sampling carried out at the lowest tide in death or full moon phases. The method used for sampling was a random method, both for transect and quadrant lines. Three random transects based local area seagrass beds in the study site and positioned perpendicular to the coastline with the size of each $50 \mathrm{~m}$. The number of quadrants to be used is 30 , each 10 quadrants for each transect, where the size of the quadrant was $50 \times 50 \mathrm{~cm}$, and the placement of the quadrants will be done by randomizing 10 quadrants on the transect line.

Seagrass samples taken in each quadrant were counted by the number of individuals of each species. Seagrass samples were identified at the Sam Ratulangi University, Faculty of Fisheries and Marine Science Laboratory. The identification process used an identification book: Lanyon (1985) (Guide to the Identification of Seagrasses in the Great Barrier Reef Region) printed by Nadicprint Services Pty. Ltd., Townsville, Queensland and some of the samples were identified at the Bogoriense Herbarium, Botany Field, Center for Biological Research - Indonesian Institute of Science, Bogor. 

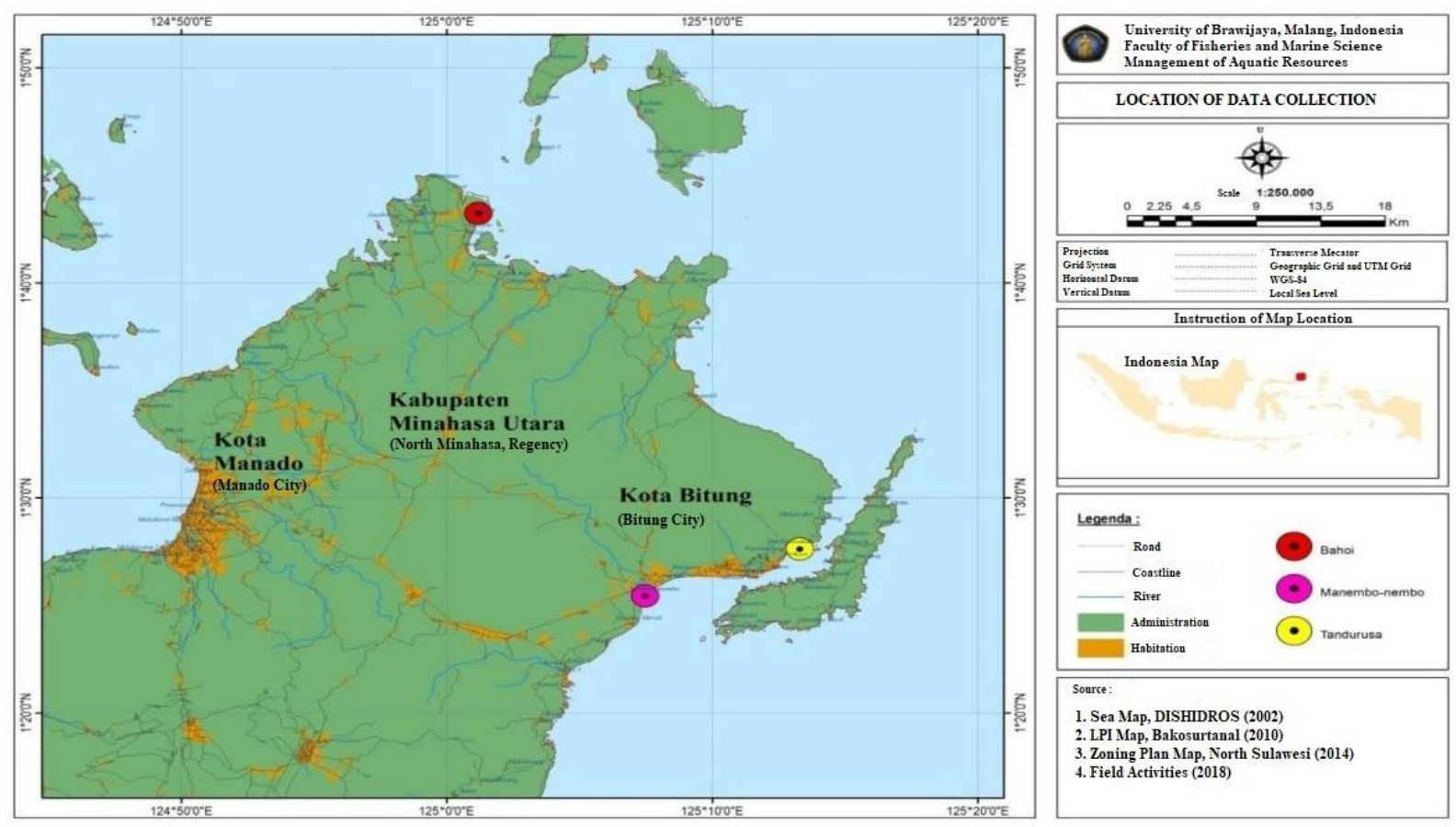

Figure 1 - Sampling Location Map

\section{RESULTS AND DISCUSSION}

Geographically, Tandurusa, Bahoi, and Manembo-nembo waters were located in the northern part of the Minahasa Peninsula, which has different environmental conditions. The factor that most influences changes in the environmental conditions in these waters is the presence of human activities, especially those close to settlements and the fishing industry. The intertidal zone in Bahoi waters of the West Likupang District of North Sulawesi was waters that have a reasonably vast tidal expanse, and there are three main coastal community communities, namely mangroves, seagrasses, and coral reefs. In Bahoi can be found several types of seagrasses. The Bahoi area was also an ecotourism area. Bahoi has natural conditions that are still very awake, i.e., the condition of seagrass, which was still very good and healthy, with a considerable diversity of seagrass species and close closure (Yunitha et al., 2014). Physically, Bahoi waters have a morphological substrate with coarser grain particles. Seagrass beds found along the Bahoi beach with an area of $\pm 16.50 \mathrm{Ha}$ (Tolule et al., 2015).

Location Tandurusa and Manembo-nembo, Bitung City, there were activities in and out of ships both domestic and ships from abroad. In addition, there are loading and unloading activities, fishing activities, and factory activities (fish and oil canning). Sampling locations in Tandurusa located between the Lembeh Strait and Bitung City, which has a narrow tidal expanse, and there are three main coastal communities, namely mangrove, seagrass, and coral reefs. In contrast, Manembo-nembo located outside the Lembeh Strait with mangrove, seagrass communities, and coral reefs. Substrates in the waters of Manembo-nembo and Tandurusa have finer grain morphology. The results showed seagrass species from the waters of Bahoi, Manembo-nembo Tandurusa, North Sulawesi included in 2 families, namely Potamogetonaceae (Figure 2) and Hydrocharitaceae (Figure 3). The observation of seagrass distribution in three research locations can saw in Table 1.

Table 1 showed that at three different locations, namely in Bahoi, Manembo-nembo, and Tandurusa, found 10 species of seagrass (seagrass) from 2 Families and 7 genera. The highest number of species was found in Bahoi with 5-7 species. The types that often found are Enhallus acaroides, Cymodocea rotundata, Halophylla ovalis, and Thalassia hemprichii. While Halophylla minor and Thallasodendrom ciliatum not found on the Bahoi. On the water of Manembo-nembo found 3-6 species. The most common type was Cymodocea rotundata. 
Whereas Halodule pinifolia, Halophila minor, and Thallasodendrom ciliatum not found in Manembo-nembo. In Tandurusa waters, 3-7 seagrass species were found, and the most common species, Enhallus acaroides. While the species that rarely found, namely Cymodocea rotundata and Thalassia hemprichii. This difference can be caused by different environmental conditions, especially from the physical and chemical factors of water and sediment/substrate (Yunitha et al., 2014).

Table 1 - Distribution of Seagrass in Bahoi, Manembo-Nembo, and Tandurusa Waters

\begin{tabular}{|c|c|c|c|c|c|c|c|c|c|c|}
\hline \multirow{2}{*}{ No } & \multirow{2}{*}{ Family and Species } & \multicolumn{3}{|c|}{ Bahoi } & \multicolumn{3}{|c|}{ Manembo-nembo } & \multicolumn{3}{|c|}{ Tandu-rusa } \\
\hline & & 1 & 2 & 3 & 1 & 2 & 3 & 1 & 2 & 3 \\
\hline \multirow[t]{6}{*}{1} & POTAMOGETONACEAE & & & & & & & & & \\
\hline & Halodule uninervis & + & - & - & + & - & - & + & - & + \\
\hline & Halodule pinifolia & + & - & - & - & - & - & - & - & + \\
\hline & Cymodocea rotundata & + & + & + & + & + & + & - & - & - \\
\hline & Cymodocea serrulata & - & - & + & + & - & + & - & + & + \\
\hline & Syringodium isoetifolium & - & + & + & - & - & + & - & - & + \\
\hline \multirow[t]{6}{*}{2} & HYDROCHARITACEAE & & & & & & & & & \\
\hline & Enhallus acoroides & + & + & + & + & + & - & + & + & + \\
\hline & Halophila minor & - & - & - & - & - & - & - & + & - \\
\hline & Halophila ovalis & + & + & + & + & + & - & - & + & + \\
\hline & Thalassia hemprichii & + & + & + & + & - & - & - & - & - \\
\hline & Thalassodendron ciliatum & - & - & - & - & - & - & + & - & + \\
\hline \multicolumn{2}{|c|}{ Total of Species } & 7 & 5 & 6 & 6 & 3 & 3 & 3 & 4 & 7 \\
\hline
\end{tabular}

Note: $(+)=$ Found $;(-)=$ Unfound .

Halodule uninervis and Halodule pinifolia can adapt to different environments through morphological changes. Seagrasses with exposed locations have short leaves with short erect stems while seagrasses that are in the shade and are always submerged have long leaves with long erect stems (Nazri, 2007). Khalafallah, Geneid, Shaetaey, \& Shaaban (2013) reported the distribution of $H$. uninervis and $H$. pinifolia ranging from Indian to western pacific oceans, including Malaysia to northern Australian, Fiji, Tonga and New Macedonia. The observations described $H$. uninervis as larger than $H$. pinifolia and growth in areas below intertidal to subtidal. $H$. uninervis has leaves that can reach $0.4 \mathrm{~cm}$, with 3 leaf veins that form teeth at the tips of the leaves. One vein in the middle of the leaf is very different where it ends in a slightly rounded tooth shape. Whereas $H$. pinifolia has 2 leaf strands with $6-14 \mathrm{~cm}$ leaf length, $0.8 \mathrm{~cm}$ leaf width, $3.5 \mathrm{~cm}$ leaf bone length and $3 \mathrm{~cm}$ length between segments. Previous studies have also reported the presence of $H$. pinifolia and $H$. uninervis in the waters of North Sulawesi, namely the Bahoi (Tolule et al., 2015); Arakan dan Tongkeina (Sakey, Wagey, \& Gerung, 2015). Morphology of Halodule uninervis and Halodule pinifolia can be seen in Figures $2 \mathrm{a}$ and $2 \mathrm{~b}$.

Cymodocea rotundata and Cymodocea serrulata were seagrass species commonly found in Indonesian waters (Ramili, Bengen, Madduppa, \& Kawaroe, 2018). C. serrulata growth in intertidal regions, and found growing together with Halophila ovalis in seagrass ecosystems (Abu Hena, Misri, Japar Sidik, Hishamuddin, \& Hidir, 2001). Whereas C. rotundata play an important role as the main food for dugongs in eastern Indonesia (Tomascik, Mah, Nontji, \& Moosa, 1997). The results showed C. rotundata has a leaf length of $10-20 \mathrm{~cm}$ and leaf width reaches $0.5 \mathrm{~cm}$, with some leaf strands of 2-3 strands. Rhizoma $0.1 \mathrm{~cm}$ in diameter and $2.8 \mathrm{~cm}$ internodes. Whereas $C$. serrulata has a leaf length of 11-22 $\mathrm{cm}$ and leaf width reaches $0.6 \mathrm{~cm}$, with some leaf strands of 2-3 strands. Rhizoma $0.12 \mathrm{~cm}$ in diameter and $2.7 \mathrm{~cm}$ internodes. Previous studies have also reported the distribution of $C$. rotundata from Bunaken and Wawontulap waters in North Sulawesi (Wagey, 2017) and distribution of $C$. serrulata from Arakan and Tongkeina Waters (Sakey et al., 2015) in North Sulawesi. The morphology of Cymodocea rotundata and Cymodocea serrulata can be seen in Figures 2c and 2d.

Syringodium isoetifolium was reportedly distributed in South Africa, the Indo-Pacific, and South Australia. S. isoetifolium easily recognized by leaf morphology were dense and solid cylindrical, slender rhizomes and loose branched roots (Clores \& Agoo, 2013). The 
observations showed $S$. isoetifolium has a smooth morphology and has a special characteristic that had cylindrical and hard leaves that arise from fine manopodial rhizoma. There are 2-3 leaves in each nod, the base of the leaf-covered by upih. The leaves reach 13 $\mathrm{cm}$ in length and $0.1 \mathrm{~cm}$ in diameter. Previous studies have reported the distribution of $S$. isoetifolium in the waters of North Sulawesi, namely the Bahoi (Tolule et al., 2015) and the Kampung Ambong (Surabi, Kondoy, \& Manu, 2018). The morphology of Syringodium isoetifolium can be seen in Figure $2 e$.

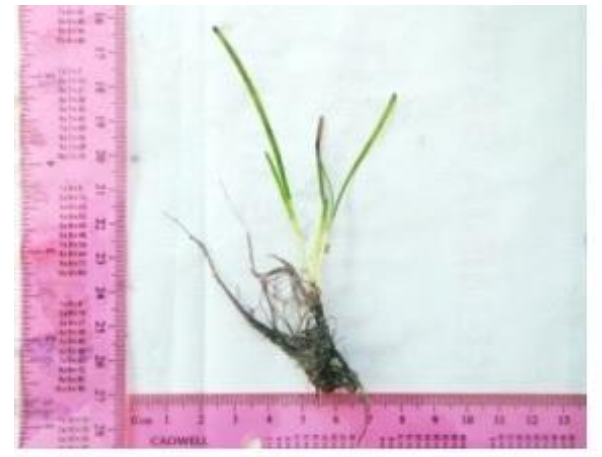

(a). Halodule uninervis

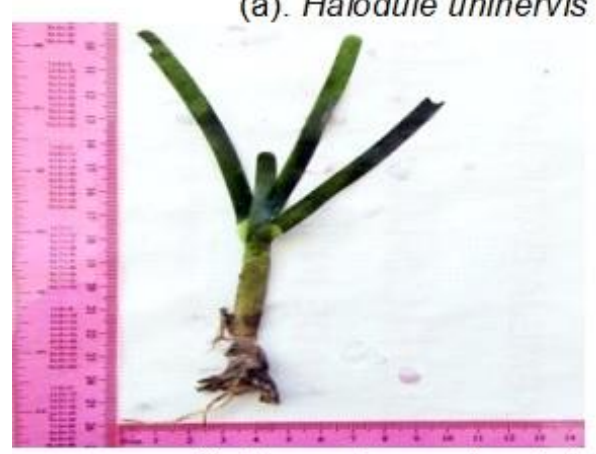

(c). Cymodocea rotundata

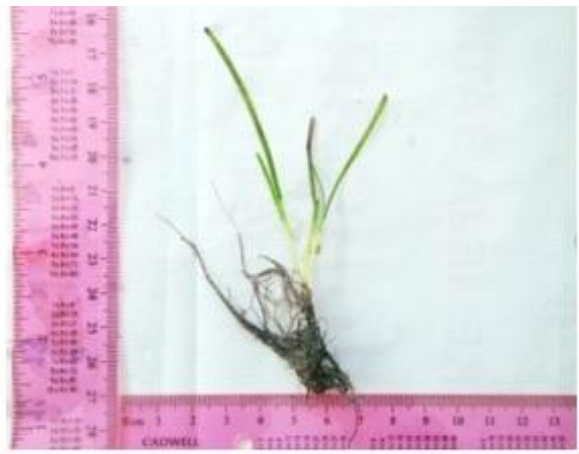

(b). Halodule pinifolia

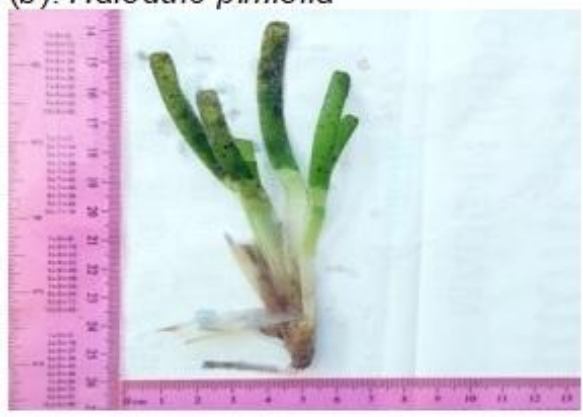

(d). Cymodocea serrulata

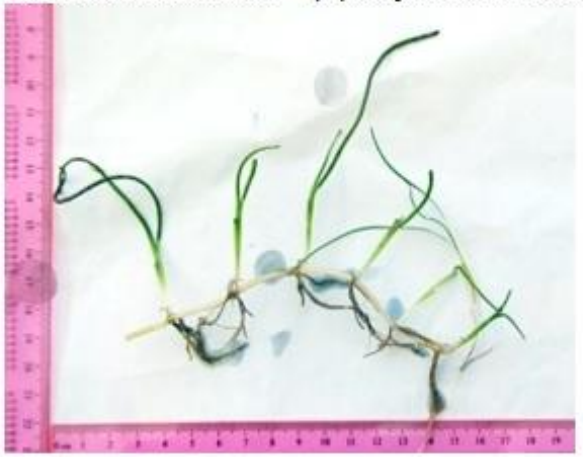

(e). Syringodium isoetifolium

Figure 2 - Seagrass Family Potamogetonaceae From North Sulawesi

Enhalus acoroides were the easiest seagrasses to distinguish from other seagrass species. Irawan \& Matuankotta (2015) states E. acoroides were easily recognizable in waters because of their unique morphology and large size. Characteristics of E. acoroides have 2-4 leaves are straight and long as the tape $(24-45 \mathrm{~cm})$ with $1 \mathrm{~cm}$ leaf width, leaf outskirts smooth and thick, and rounded at the apex. Rhizoma diameter of $1 \mathrm{~cm}$ and surrounded by thick black fibers. Stem thick and upright. The results of the study Hartati et al. (2017) also explained the characteristics of $E$. acoroides which have leaves that were shaped like a ribbon with a leaf length of $20 \mathrm{~cm}$ and a width of almost $2 \mathrm{~cm}$. The type of rhizome was $1 \mathrm{~cm}$ thick and the roots were hard and thick with a size of 0.3-0.5 cm. Pharmawati et al. (2015) stated that $E$. acoroides was a common seagrass species found in Indonesia, which was 
spread in Java, Kalimantan, Sumatra, Sulawesi, Ambon, Papua, and Nusa Tenggara. The morphology of Enhalus acoroides can be seen in Figure 3a.

Thalassia hemprichii was a common type of seagrass distributed in the Indo-Pacific region. Xu, Huang, Huang, Zhu, \& Zhang (2009) reported T. hemprichii biomass spread from Southeast Asia, South Taiwan, Kenya, Mozambique and the Arabian Sea. Observation showed T. hemprichii has a smooth rhizoma with short shoots on each segment, where there were 2-7 leaves, with a round apex and smooth, 9-16 fibrous fibers. The leaves were straight to curved with a leaf length of $5-10 \mathrm{~cm}$ and a width of $0.2-0.9 \mathrm{~cm}$. Previous studies reported the distribution of $T$. hemprichii in North Sulawesi waters, namely Mantehage (Patty \& Rifai, 2014), Tongkeina (Kondoy, Herawati, Mahmudi, \& Azrianingsih, 2014), and Lembeh (Rustam et al., 2016). The morphology of Thalassia hemprichii can be seen in Figure 3b.

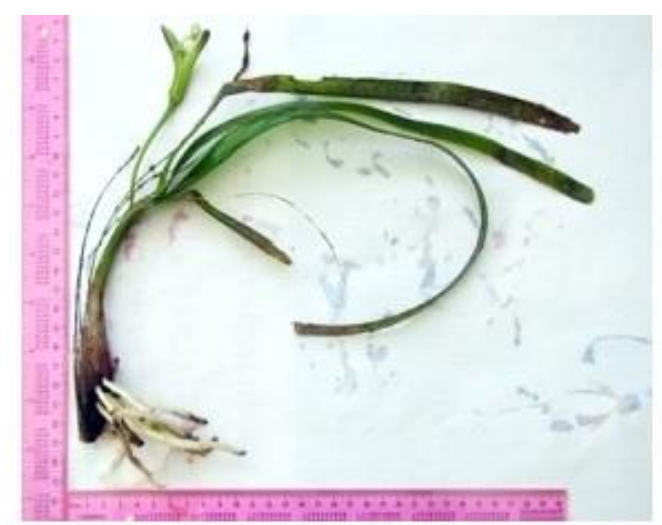

(a). Enhalus acoroides

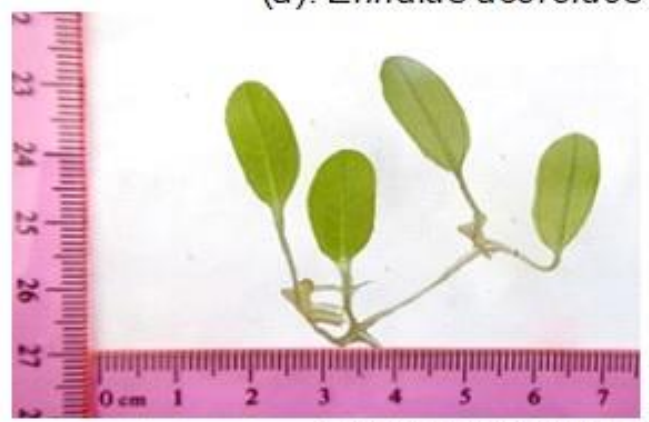

(c). Halophila minor

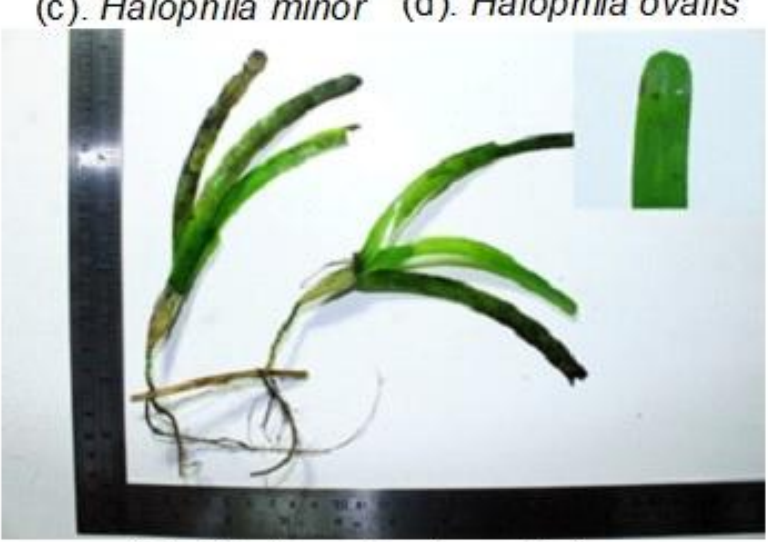

(e). Thalassodendron ciliatum

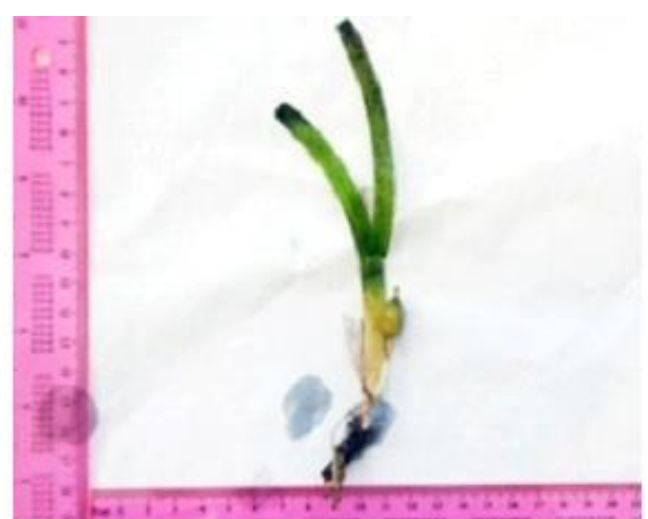

(b). Thalassia hemprichii

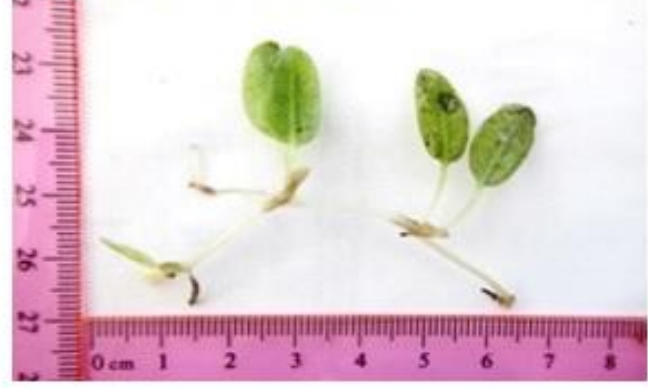

(d). Halophila ovalis

Figure 3 - Seagrass Family Hydrocharitaceae From North Sulawesi

Halophila minor and Halophila ovalis was a species of seagrass commonly found in tropical waters (Short, Carruthers, Dennison, \& Waycott, 2007). H. minor reported to live on protected beaches on mud, sand or coral debris substrates. $H$. minor was commonly found in deep bays that were protected from wave action (Phillips, Menez, \& Calumpong, 1983). H. minor and $H$. ovalis were pioneers (Razalli et al., 2011) and were common on muddy 
substrates, can be the dominant species in intertidal areas and can grow to depths of $25 \mathrm{~m}$. $H$. minor has leaf blades that were very similar to $H$. ovalis but smaller. The observations showed $H$. minor leaf strands had a length of 0.7 to $1.4 \mathrm{~cm}$ and the number of leaf veins of 3 to 8 pairs. Whereas $\mathrm{H}$. ovalis has a leaf length of $2.5 \mathrm{~cm}$, leaf width of $0.8 \mathrm{~cm}$, leaf middle veins 10-20 pairs of transverse veins, leaf bone length of $3.5 \mathrm{~cm}$, length of the distance between segments $2.8 \mathrm{~cm}$ with rhizoma diameter 0.01-0.1 cm. Surabi et al. (2018) reported the presence of $H$. minor from the waters of Kampung Ambong, North Sulawesi. Whereas $H$. ovalis from Arakan, Manado Bay, Tongkeina, Siladen, Mantehage, Likupang, and Tanjung Merah, North Sulawesi (Wagey, Lasabuda, Tilaar, \& Katuuk, 2016). Morphology of Halophila minor and Halophila ovalis can be seen in Figure $3 c$ and $3 d$

Thalassodendron ciliatum reportedly distributed throughout the Indian Ocean and Southeast Asian waters (Duarte, Hemminga, \& Marbà, 1996). The results described $T$. ciliatum as having a broad rhizome with a length of 1.5 to $3.0 \mathrm{~cm}$. Stems reach 10 to $65 \mathrm{~cm}$. $T$. ciliatum leaves were shaped like a ribbon. The roots and rhizomes of $T$. ciliatum were very strong so that $T$. ciliatum was suitable for living in various types of sediments including around coral blocks. Bandeira (2002) reported T. ciliatum can live on rocky substrates with strong currents of water, waves and wind. (Patty \& Rifai, 2014) reported the existence of $T$. ciliatum in the waters of Mantehage, North Sulawesi. In addition, the distribution of $T$. ciliatum also reported in Philippine waters close to Sulawesi waters (Meñez \& Calumpong, 1982). The morphology of the Thalassodendron ciliatum can be seen in Figure $3 e$.

The dense of seagrass ecosystems will be more favorable for marine life from attack prey (predators) to perform detection, chase and capture prey becomes lower. Information on the distribution of seagrasses in an area was important, especially for public knowledge. Also, information on the distribution of seagrasses in an area can take into consideration for the government and related agencies in drafting a regulation in the management of marine resources and general knowledge of the role of seagrass ecosystems on current global issues, namely global climate change.

\section{CONCLUSION}

The distribution of seagrasses on the Bahoi, Manembo-nembo, and Tandurusa was dominated by Enhallus acoroides, followed by Halophila ovalis and Cyamodocea rotundata. In the Bahoi found 8 species of seagrass, Menembo-nembo found 7 species, while in Tandurusa found 9 species.

\section{REFERENCES}

1. Abu Hena, M. K., Misri, K., Japar Sidik, B., Hishamuddin, O., \& Hidir, H. (2001). Photosynthesis of seagrass Cymodocea serrulata (Magnoliophyta / Potamogetonales / Cymodoceaceae) in field and laboratory. Indian Journal of Marine Sciences, 30(4), 253256.

2. Amale, D., Kondoy, K. I. F., \& Rondonuwu, A. B. (2016). Morphometric Structure of Seagrass Halophila ovalis in Tongkeina, Bunaken Subdistrict, Manado City and Mokupa, Tombariri Subdistrict, Minahasa District Coastal Waters. Jurnal IImiah Platax, 4(2), 6775. https://doi.org/10.1109/ciced.2018.8592188 [In Indonesian].

3. Bandeira, S. O. (2002). Leaf production rates of Thalassodendron ciliatum from rocky and sandy habitats. Aquatic Botany, 72(1), 13-24. https://doi.org/10.1016/S03043770(01)00192-9.

4. Clores, M. A., \& Agoo, E. M. (2013). Flowering distribution and fruiting success of Syringodium isoetifolium (Cymodoceaceae) in Bogtong Bay, Lahuy island, Caramoan, Philippines. Academic Research International, 4(4), 14-29.

5. Duarte, C. M., Hemminga, M. A., \& Marbà, N. (1996). Growth and population dynamics of Thalassodendron ciliatum in a Kenyan back-reef lagoon. Aquatic Botany, 55(1), 1-11. https://doi.org/10.1016/0304-3770(96)01066-2.

6. Fahruddin, M., Yulianda, F., \& Setyobudiandi, I. (2017). Density and The Coverage of 
Seagrass Ecosystem in Bahoi Village Coastal Waters, North Sulawesi. Jurnal IImu Dan Teknologi Kelautan Tropis, 9(1), 375-383. [In Indonesian].

7. Hartati, R., Widianingsih, W., Santoso, A., Santoso, A., Endrawati, H., Zainuri, M., ... Mahendrajaya, R. T. (2017). Variasi Komposisi Dan Kerapatan Jenis Lamun Di Perairan Ujung Piring, Kabupaten Jepara. Jurnal Kelautan Tropis, 20(2), 96-105. https://doi.org/10.14710/jkt.v20i2.1702 [In Indonesian].

8. Hogarth, P. (2007). The Biology of Mangroves and Seagrasses (Second). New York: Oxford University Press.

9. Irawan, A., \& Matuankotta, C. (2015). Enhalus acoroides, The Biggest Seagrass in Indonesia. Oseana, $\mathrm{XL}(1), 19-26$. [In Indonesian].

10. Khalafallah, A. A., Geneid, Y. A., Shaetaey, S. A., \& Shaaban, B. (2013). Responses of the seagrass Halodule uninervis (Forssk.) Aschers. to hypersaline conditions. Egyptian Journal of Aquatic Research, 39(3), 167-176. https://doi.org/10.1016/j.ejar.2013.10.003

11. Kiswara, W. (2004). Kondisi Padang Lamun (seagrass) di Teluk Banten 1998 - 2001. Jakarta. [In Indonesian].

12. Kiswara, W., \& Winardi. (1999). Sebaran lamun di Teluk Kuta dan Teluk Gerupuk, Lombok. Jakarta. [In Indonesian].

13. Kondoy, K. I. F., Herawati, E. Y., Mahmudi, M., \& Azrianingsih, R. (2014). CO2 application as growth stimulator of sea grass, Thalassia hemprichii under laboratory conditions. Journal of Biodiversity and Environmental Sciences, 5(6), 153-159.

14. Lanyon, J. (1985). Guide to the Identification of sea grass in the Great Barrier Reef Region. Great Barrier Marine Park Authoryng Special Publication Series (3). Townsvaille, Queensland: Nadicprint Services Pty. Ltd.

15. Lanyon, J., Limpus, C. J., \& Marsh, H. (1989). Dugongs and turtles; Grazers in the sea grass system. In A. W. D. Larkum, A. J. McComb, \& S. A. Sheperd (Eds.), Biology of Australian sea grasses, An Australian perspective (p. 471). Amsterdam: Elsevier.

16. Maabuat, P. V. (2012). Keanekaragaman Lamun di Pesisir Pantai Molas, Kecamatan Bunaken Kota Manado (Biodiversity of Seagrass on Molas Seashore in Bunaken Subdistrict, Manado). Jurnal Bios Logos, 2(1). https://doi.org/10.35799/jbl.2.1.2012.376 [In Indonesian].

17. Meñez, E. G., \& Calumpong, H. P. (1982). Thalassodendron ciliatum: An unreported seagrass in the Philippines. Micronesica, 18(December), 103-108.

18. Nazri, N. A. (2007). Assessment of Morphological Variation of Malaysian Halodule Species Complex. Thesis. Universiti Putra Malaysia.

19. Patty, S. I., \& Rifai, H. (2014). Community Structure of Seagrass Meadows In Mantehage Island Waters, North Sulawesi. Jurnal Ilmiah Platax, 1(4), 177-186. https://doi.org/10.35800/jip.1.4.2013.3699 [In Indonesian].

20. Pharmawati, M., Putra, I. N. G., Syamsuni, Y. F., \& Mahardika, I. G. N. K. (2015). Genetic diversity of Enhalus acoroides (L.) royle from coastal waters of Pramuka Island, Lembongan Island, and Waigeo Island, Indonesia, based on microsatellite DNA. Advanced Science Letters, 21(2), 199-202. https://doi.org/10.1166/asl.2015.5861.

21. Phillips, R. C., \& Menez, E. G. (1988). Seagrasses. In Smithsonian Contributions to the marine Sciences (Vol. 34). https://doi.org/10.1007/978-90-481-2639-2_146.

22. Phillips, R. C., Menez, E. G., \& Calumpong, H. P. (1983). Seagrasses from the Philippines. Smithsonian Contributions to the Marine Sciences, (21), 1-40. https://doi.org/10.5479/si.01960768.21.

23. Ramili, Y., Bengen, D. G., Madduppa, H. H., \& Kawaroe, M. (2018). Morphometric characteristics of two seagrass species (Enhalus acoroides and Cymodocea rotundata) in four small islands in North Maluku, Indonesia. Biodiversitas, 19(6), 2035-2043. https://doi.org/10.13057/biodiv/d190608.

24. Razalli, N. M., Peng, T. C., Yusof, M. S. M., Mohamed, J., Hwai, T. S., Yasin, Z., \& Abdullah, A. L. (2011). Distribution and Biomass of Halophila ovalis (R. Brown) Hook. f. at Pulau Gazumbo, Penang, Straits of Malacca. Publications of the Seto Marine Biological Laboratory, 41, 71-76. https://doi.org/10.1017/CBO9781107415324.004.

25. Romimohtarto, K., \& Juwana, S. (2005). Biologi Laut. Ilmu Pengetahuan Tentang Biota. 
(Second). Jakarta: Djambatan. [In Indonesian].

26. Rustam, A., Kepel, T. L., Kusumaningtyas, M. A., Ati, R. N. A., Daulat, A., Suryono, D. D., ... Hutahaean, A. A. (2016). Seagrass Ecosystem As Environmental Bioindicator In Lembeh Island, Bitung, North Sulawesi. Jurnal Biologi Indonesia, 11(2), 233-241. https://doi.org/10.14203/jbi.v11i2.2197 [In Indonesian].

27. Sakey, W. F., Wagey, B. T., \& Gerung, G. S. (2015). Variasi morfometrik pada beberapa lamun di perairan semenanjung minahasa. Jurnal Pesisir Dan Laut Tropis, 1(1), 1-7.

28. Short, F., Carruthe[In Indonesian]rs, T., Dennison, W., \& Waycott, M. (2007). Global seagrass distribution and diversity: A bioregional model. Journal of Experimental Marine Biology and Ecology, 350(1-2), 3-20. https://doi.org/10.1016/j.jembe.2007.06.012.

29. Supriyadi, I. H. (2012). The Importance of Indonesian Seagrass Ecosystem Mapping Information. Oseana, XXXVII(1), 25-38. [In Indonesian].

30. Surabi, A., Kondoy, K. I. F., \& Manu, G. D. (2018). Seagrass Community At Kampung Ambong's Water East Likupang Subdistrict, North Minahasa Regency. Jurnal Ilmiah Platax, 6(1), 12-20. [In Indonesian].

31. Tanod, W. A., Dewanto, D. K., Ndobe, S., Riyadi, P. H., \& Putra, M. Y. (2019). Screening of Antibacterial and Antioxidant Activity from the Soft Corals Sinularia sp. and Sarcophyton sp. Origin Palu Bay, Central Sulawesi, Indonesia. Squalen Bulletin of Marine and Fisheries Postharvest and Biotechnology, 14(2), 73-83. https://doi.org/10.15578/squalen.v14i2.394.

32. Tolule, K., Kambey, A. D., \& Rondonuwu, A. B. (2015). Community Structure of Seagrass in Coastal Waters of Bahoi Village, West Likupang Sub-district, North Minahasa Regency, North Sulawesi Province. Jurnal IImiah Platax, 3(2), 63-67. [In Indonesian].

33. Tomascik, T., Mah, A. ., Nontji, A., \& Moosa, M. . (1997). The ecology of Indonesian Seas (Part II). Singapore: Periplus.

34. Wagey, B. T. (2017). Morphometric analysis of congeneric seagrasses (Cymodocea rotundata and Cymodocea serrulata) in the coastal areas of Bunaken National Park, North Sulawesi, Indonesia. AACL Bioflux, 10(6), 1638-1646.

35. Wagey, B. T., Lasabuda, R., Tilaar, F., \& Katuuk, V. (2016). Spatial Morphological Variability of the Seagrass Halophila ovalis (R.Br.) Hooker $f$ in Minahasa Peninsula waters. Asian Journal of Biodiversity, 7(January), 56-78. https://doi.org/10.1017/CBO9781107415324.004.

36. Wagey, B. T., \& Sake, W. (2013). Variasi Morfometrik Beberapa Jenis Lamun Di Perairan Kelurahan Tongkeina Kecamatan Bunaken. Jurnal Pesisir Dan Laut Tropis, 3(1), 36-44. https://doi.org/10.35800/jplt.1.3.2013.4354 [In Indonesian].

37. Wangkanusa, M. S., Kondoy, K. I. F., \& Rondonuwu, A. B. (2017). Study on Density and morphometrics of seagrass Enhalus acoroides from Different Substrates on Coastal Waters of Tongkeina, City of Manado. Jurnal Ilmiah Platax, 5(2), 210-220. [In Indonesian].

38. Xu, Z., Huang, L., Huang, X., Zhu, A., \& Zhang, S. (2009). Growth strategy of seagrass Thalassia hemprichii in Xincun Bay near Hainan Island of China. Marine Science Bulletin, 11(1), 15-19. Retrieved from http://isbw11.csp.escience.cn/.

39. Yunitha, A., Wardiatno, Y., \& Yulianda, F. (2014). Diameter Substrat Dan Jenis Lamun Di Pesisir Bahoi Minahasa Utara: Sebuah Analisis Korelasi. Jurnal IImu Pertanian Indonesia, 19(3), 130-135. [In Indonesian]. 